DOE/RL-93-94

Revision 0

\title{
Plan and Schedule for Disposition and Regulatory Compliance for Miscellaneous Streams
}

Date Published

January 1994

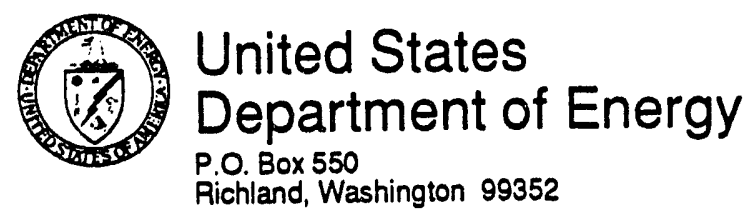

Approved for Public Release 


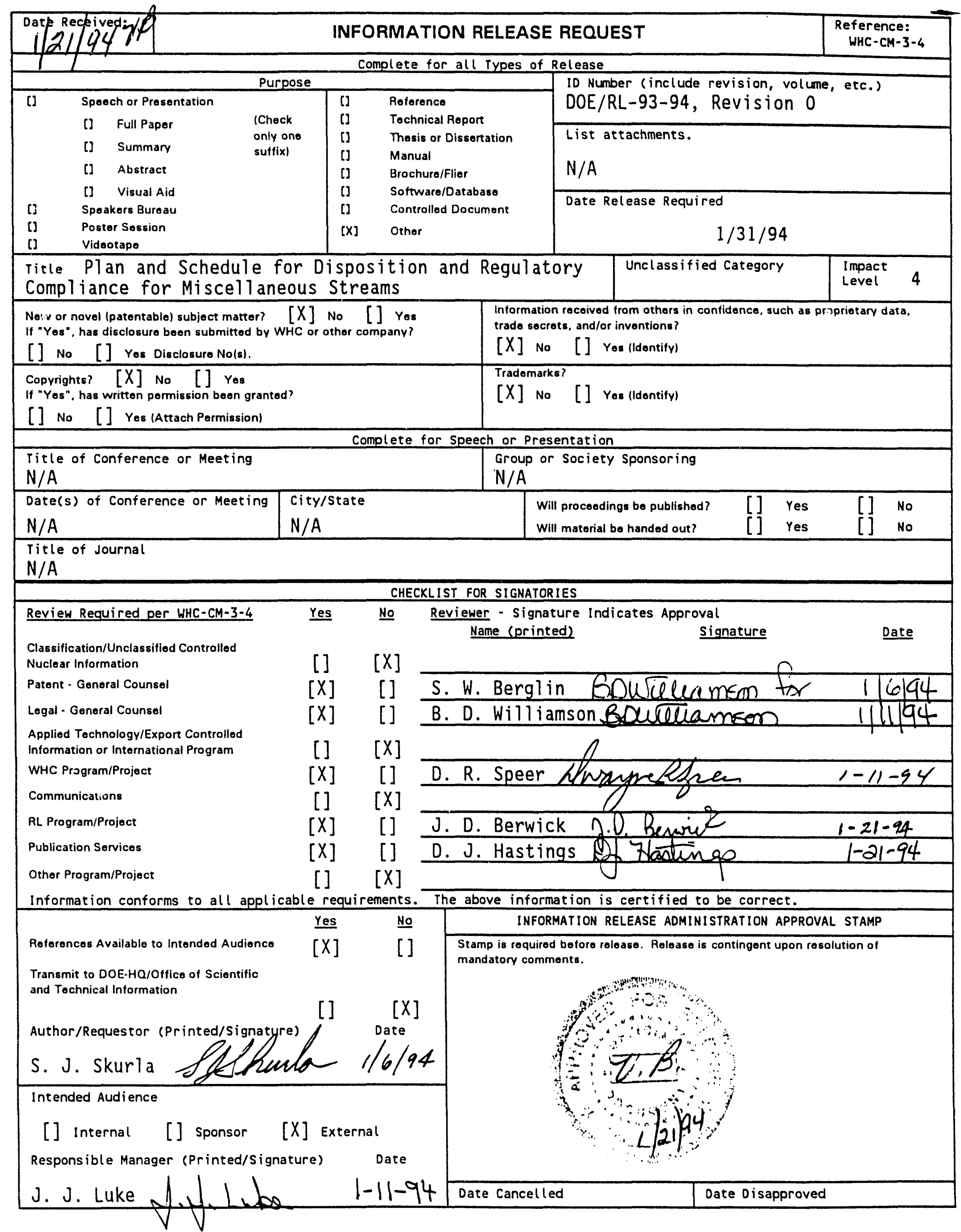


CONTENTS

$1.0 \quad$ INTRODUCTION $\ldots \ldots \ldots \ldots \ldots \ldots \ldots \ldots$

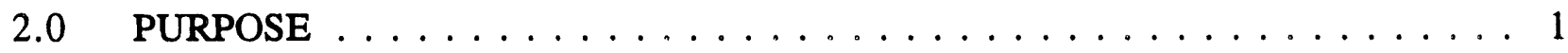

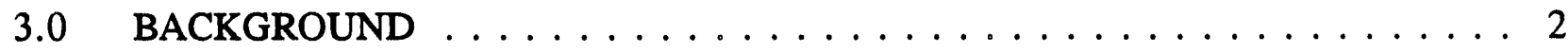

3.1 CONSENT ORDER MILESTONES FOR MISCELLANEOUS

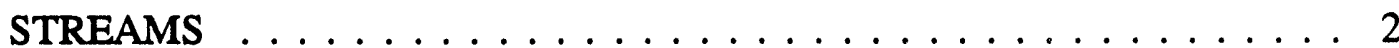

3.2 STATE WASTE DISCHARGE PERMIT PROGRAM AND THE UNDERGROUND INJECTION CONTROL PROGRAM . . . . . . . 3

4.0 DEFINITION OF MISCELLANEOUS STREAMS AND STREAM CATEGORIES $\ldots \ldots \ldots \ldots \ldots \ldots \ldots \ldots \ldots$

5.0 PLAN FOR DISPOSITION AND REGULATORY COMPLIANCE OF

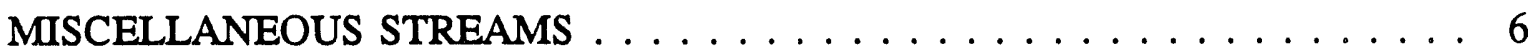

5.1 CLARIFICATION AND JUSTIFICATION - FIGURE 5-1, PAGE $1 \ldots 7$

5.2 CLARIFICATION AND JUSTIFICATION - FIGURE 5-1, PAGE $2 \ldots .11$

5.3 CLARIFICATION AND JUSTIFICATION - FIGURE 5-1, PAGE $3 \ldots 13$

6.0 SCHEDULE FOR DISPOSITION AND REGULATORY COMPLIANCE OF MISCELLANEOUS STREAMS $\ldots \ldots \ldots \ldots \ldots \ldots \ldots$

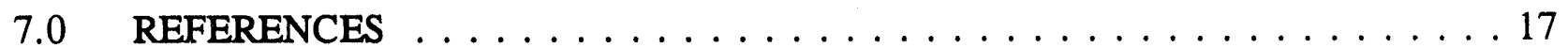

7.1 DOCUMENTS AND LETTERS . . . . . . . . . . . . . . . 17

7.2 CODE OF FEDERAL REGULATIONS AND FEDERAL REGISTER . . 17

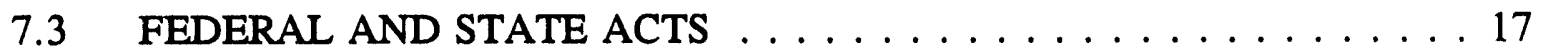

7.4 WASHINGTON ADMINISTRATIVE CODE $\ldots \ldots \ldots \ldots \ldots 17$

FIGURE

5-1 Plan for Disposition of Miscellaneous Streams

Discharging to Land $\ldots \ldots \ldots \ldots \ldots \ldots \ldots \ldots \ldots$

TABLE

6-1 Schedule for Disposition and Regulatory Compliance of the Miscellaneous Streams . . . . . . . . . . . . . . . . . . . 16 


\section{PLAN AND SCHEIUULE FOR DISPOSITION AND REGULATORY COMPLIANCE FOR ALL REMAINING MISCELLANEOUS STREAMS}

\subsection{INTRODUCTION}

On December 23, 1991, the U.S. Department of Energy, Richland Operations Office (RL) and the Washington State Department of Ecology (Ecology) agreed to adhere to the provisions of Department of Ecology Consent Order No. DE 91 NM-177 (Consent Order) (Ecology and USDOE, 1991). The Consent Order lists regulatory milestones for liquid effluent streams at the Hanford Site to comply with the permitting requirements of Washington Administrative Code 173-216 or 173-218 where applicable (WAC 173-216/218).

Hanford Site liquid effluent streams discharging to the soil column have been categorized in the Consent Order as follows:

- Phase I Streams

- Phase II Streams

- Miscellaneous Streams.

Phase I and Phase II Streams are identified in two RL reports: "Plan and Schedule to Discontinue Disposal of Contaminated Liquids into the Soil Column at the Hanford Site" (DOE-RL 1987), and "Annual Status of the Report of the Plan and Schedule to Discontinue Disposal of Contaminated Liquids into the Soil Column at the Hanford Site" (Stordeur 1988). There are 33 Phase I and Phase II Streams. Miscellaneous Streams are those liquid effluent streams discharged to the ground that are not categorized as Phase I or Phase II Streams.

Miscellaneous Streams discharging to the soil column at the Hanford Site are subject to the requirements of several milestones identified in the Consent Order. This document provides a plan and schedule for the disposition of Miscellaneous Streams to satisfy one of the Miscellaneous Stream Consent Order requirements. The disposition process for the Miscellaneous Streams as developed for this milestone is facilitated using a decision tree format. The logic diagram and corresponding analysis for determining appropriate disposition of these streams is presented in this document. The options for disposition of the Miscellaneous Streams have been selected based on demonstrating compliance with the intent of the Hanford Federal Facility Agreement and Consent Order (Tri-Party Agreement) (Ecology, et al., 1992), Consent Order, WAC 173-216, WAC 173-218, WAC 173-226, and RCW 90.48.

\subsection{PURPOSE}

This document satisfies the Milestone in Section 6 of the Consent Order to "submit a plan and schedule for disposition and regulatory compliance for all remaining Miscellaneous Streams to Ecology for approval by 1/94." This Milestone is applicable to all Miscellaneous streams inventoried as a result of implementing the "Plan and Schedule for Identification and 
Evaluation for all Miscellaneous Streams," (WHC 1992) submitted to Ecology in September 1992.

\subsection{BACKGROUND}

As part of Tri-Party Agreement negotiations, RL, Ecology, and U.S. Environmental Protection Agency (EPA) agreed that liquid effluents discharged to the soil column would be regulated in accordance with the M-17 series of milestones as set forth in the Tri-Party Agreement.

The three parties, RL, Ecology and EPA, agreed in the Second Amendment of the Tri-Party Agreement, September 9, 1991: ". . . that those waste water streams currently discharged to the soil column or future waste water streams (excluding discharges that are exempt from permitting under Section 121 of the Comprehensive Environmental Response, Compensation and Liability Act), which affect ground water or have the potential to affect ground water, shall be subject to regulatory permitting under RCW 90.48.160, WAC 173216, or if applicable, WAC 173-218." (Ecology, et. al., 1992) The three parties further agreed that RL and Ecology rould negotiate a separate agreement by September 1991, or a later date as agreed upon by the necessary actions leading to obtaining such permits at the Hanford Site. That agreement, the Ecology Consent Order DE 91NM-177, was signed by RL and Ecology on December 23, 1991.

\subsection{CONSENT ORDER MILESTONES FOR MISCELLANEOUS STREAMS}

Section 6 of the Consent Order stipulates several milestones for miscellaneous streams. Table 4 of Section 6 promulgates a schedule for the submittal of WAC 173$216 / 218$ permit applications for eleven miscellaneous streams and corresponding disposal sites. The Consent Order specifically allows for any liquid effluent stream that is discontinued or rerouted, prior to the submittal date for any pertinent regulatory milestone, to be exempted from the milestone requirements for that effluent stream. However, if rerouted (which may occur only with Ecology approval), the liquid effluent stream shall assume the submittal date for any pertinent regulatory milestone established for the effluent treatment, collection, conveyance, storage or disposal facility it is rerouted to, in accordance with Tables 1 through 6 of the Consent Order.

Three milestones in Section 6 apply to miscellaneous streams not identified in Table 4:

- Submit revised "Inventory of Disposal Sites for Miscellaneous Stream, July, 1991" to Ecology by August 1992.

- Submit a plan which includes an overall regulatory strategy, methodology, and schedule for identification and evaluation of all Miscellaneous Streams by September 1992. 
- Submit a plan and schedule for disposition and regulatory compliance for all remaining Miscellaneous Streams to Ecology for approval by January 1994.

The requirements of the first and second milestone listed above have been met through the submittal of the "Revised Inventory of Miscellaneous Streams, August 1992", and the "Plan for Identification and Evaluation of All Miscellaneous Streams (September 1992)", respectively. This document will satisfy the requirements of the third milestone.

Section 7 of the Consent Order specifies that WAC 173-216/218 permits shall not be required for liquid effluent streams that:

- remain discontinued,

- are currently discharging to ground but shall not continue to discharge to ground after June 1995,

- are permitted through the NPDES, or through an Ecology approved pretreatment program, where applicable.

Although this statement is provided under the section heading of "Phase I and Phase II Liquid Effluents for which WAC 173-216 (WAC 173-218 where applicable) Permits Shall not be Required," the intent is considered applicable to miscellaneous streams as well.

\subsection{STATE WASTE DISCHARGE PERMIT PROGRAM AND THE UNDERGROUND INJECTION CONTROL PROGRAM}

The State Waste Discharge Permit (SWDP) Program described in WAC 173-216 applies to the discharge of waste materials from industrial, commercial, and municipal operations into ground and surface waters of the state and into municipal sewer systems. WAC 173-216 does not apply to the following:

- The point source discharge of pollutants into navigable waters of the state which are regulated by the National Pollutant Discharge Elimination System (NPDES) Permit Program described in WAC 173-220.

- The discharge of pollutants into waters of the state which are regulated by the State Waste Discharge General Permit Program described in WAC 173-226.

- The injection of fluids through wells which are regulated by the Underground Injection Control Program described in WAC 173-218.

The Consent Order requires that liquid effluents at the Hanford Site be subjected to certain regulatory milestones for complying with the WAC 173-216/218 permitting requirements. The Consent Order addresses discharges to the soil column, and does not promulgate milestones for liquid effluent discharges permitted through the NPDES process. 
The State Waste Discharge General Permit Program, defined in WAC 173-226, became effective in May 1993. At the time the Consent Order was agreed upon (December 1991), the liquid effluent discharges at Hanford were considered to be best addressed through WAC 173-216, the State Waste Discharge Program. WAC 173-226, the State Waste Discharge General Permit Program was not yet effective at the time of the Consent Order negotiations. However, WAC 173-226 is considered to be a viable option for permitting selected liquid effluent discharges at Hanford while continuing to satisfy the intent of the Consent Order. A general permit covers multiple discharges within a designated geographical area, in lieu of individual permits being issued to each discharger. As stated in WAC 173-226-060, "For all general permits, the department [Ecology] shall make a preliminary determination to develop a general permit. Interested persons may petition the director requesting that a category of discharges be considered for the development of a general permit."

The State Underground Injection Control Regulations are provided in WAC 173-218. The Consent Order recognizes the applicability of WAC 173-218 to govern liquid effluent discharges to the subsurface through a well at the Hanford Site. A well is any bored, drilled or driven shaft, or dug hole whose depth is greater than the largest surface dimension. If the discharge is a waste fluid, WAC 173-218-090 refers to WAC 173-216 requirements for obtaining a State Waste Discharge Permit. If the discharge is not a waste fluid, or any other waste whose underground injection is prohibited by WAC 173-218, a class V injection well notification or registration form may be submitted and must include all required information.

\subsection{DEFINITION OF MISCELLANEOUS STREAMS AND STREAM CATEGORIES}

Implementation of the "Plan for Identification and Evaluation of All Miscellaneous Streams (September 1992)" (WHC 1992) provided an inventory of miscellaneous liquid effluent streams discharging to the soil column at the Hanford Site. The inventory has been segregated into a quantitative inventory and a qualitative inventory. The quantitative inventory was compiled to provide an estimate of total discharge rates and quantities for those types of streams that may be considered to potentially contain contaminants or discharge within or to a surface contaminated area. The qualitative inventory consists of stream categories that are not expected to affect ground water or have the potential to affect ground water; are being discontinued or rerouted; or are managed under a separate agreement with Ecology. Information regarding the number of streams within a category and the discharge rates were not considered necessary for the types of streams included in the qualitative inventory.

The Miscellaneous Streams quantitative inventory has been categorized into the following stream types:

- Steam condensate discharges

- Storm water discharges

- HVAC cooling water 
- Filter backwash

- $\quad$ Sink drains

- Well pump leakage

- Safety showers

- Other.

This inventory consists of approximately 400 individual streams. The total gallons per minute as a rate of liquid effluent discharged to the soil column for all miscellaneous streams included in the inventory is approximately 145 gallons per minute. Steam condensate discharges make up approximately $73 \%$ of the total number of Miscellaneous Streams and $95 \%$ of the total volume of Miscellaneous Streams included in the inventory. Storm water discharges make up approximately $15 \%$ of the total number of Miscellaneous Streams and 3\% of the total volume of Miscellaneous Streams. The remaining streams constitute less than $12 \%$ of the total number of Miscellaneous Streams and less than $2 \%$ of the total volume.

The following types of routine liquid effluent discharges to the soil make up the qualitative inventory and are not included in the quantitative Miscellaneous Stream inventory:

- Effluent streams that will be eliminated by June 1995, or routed to and included in a treatment facility and/or effluent stream permit or application for permit under WAC 173-216.

- Purge water resulting from well sampling, well development, well rehabilitation and aquifer testing. Purge water from these activities is discharged and managed according to an agreement between DOE, Ecology, and EPA on August 21, 1990 (DOE-RL 1990).

- Fire sprinkler testing wastewater - Fire sprinkler tests check for free water flow and ensure that gauges, flow switches, pressure switches, and by-pass valves operate per design. All sprinkler tests use sanitary water only.

- Wastewater from cleaning of transportation equipment - Sanitary water is used for the washing of all vehicles on site (e.g., cars, buses, trucks).

- Irrigation water (raw or sanitary) used for aesthetics such as lawns, trees, and shrubs.

- Condensate and cooling water (sanitary) from HVAC units in office facilities.

- Raw or sanitary water used for construction and dust control.

- Sanitary water used for hydrostatic testing of equipment. 
With the exception of streams to be eliminated by June 1995, or rerouted to a permitted treatment facility and/or stream and the purgewater, the plan for disposition of all Miscellaneous Streams (in both quantitative and qualitative inventories) is presented in Section 5.0.

\subsection{PLAN FOR DISPOSITION AND REGULATORY COMPLIANCE OF MISCELLANEOUS STREAMS}

The primary objective for compiling the inventory was to identify types and categories of Miscellaneous Streams for subsequent evaluation to determine regulatory and permitting requirements. This evaluation is presented as a logic diagram in Figure 5-1 and provides the plan for disposition and regulatory compliance of the Miscellaneous Streams. The plan has been developed to identify a process for managing Miscellaneous Streams in accordance with the applicable regulations stated in WAC 173-216, 173-218, and/or 173-226 and Chapter $90.48, \mathrm{RCW}$. The strategy developed includes the following elements:

- Establishment of a 'de minimus' discharge rate below which no permit or registration would be sought,

- Identifying and implementing "Best Management Practices" (BMP) for those streams which have a significant potential to be contaminated or are discharged close to known contaminated areas,

- Submission of WAC 173-216 permit applications for those waste streams which have significance in terms of high flow rates,

- Registering discharges to injection wells under WAC 173-218,

- Registering sanitary sewage systems with a capacity of less than 10,500 gallons per day under WAC 246-272, and

- Petitioning the State of Washington for a general permit under WAC 173-226 for all other waste streams.

This strategy was developed based upon the strict requirements of WAC regulations and further discussions with representatives of the Washington State Department of Ecology and the Environmental Protection Agency. The intent is to ensure proper State involvement with the permitting of waste discharges while not wasting State of Washington and Department of Energy resources on discharges which have no significance in terms of potential to pollute the ground waters. This strategy and logic is further strengthened by the language found in the Tri-Party Agreement which requires the permitting of only those streams that "affect the ground water or have the potential to affect the ground water".

The logic diagram in Figure 5-1 utilizes a series of criteria to determine the appropriate disposition and/or regulatory action for a Miscellaneous Stream or categories of 
Miscellaneous Streams. Application of the criteria in Figure 5-1 will result in one of the following determinations or actions for the Miscellaneous Streams:

- Permit under WAC 173-226, the State Waste Discharge General Permit Program.

- Permit under WAC 173-216, the State Waste Discharge Permit Program.

- Register as an injection well under WAC 173-218, the Underground Injection Control Program.

- Register as an injection well under WAC 173-218, the Underground Injection Control Program and permit under WAC 173-226, the State Waste Discharge General Permit Program.

- No permits or registration required.

- Eliminate discharge of Miscellaneous Stream.

The following sections provide clarification and justification for the logic and decision tree analysis presented in Figure 5-1.

\subsection{CLARIFICATION AND JUSTIFICATION - FIGURE 5-1, PAGE 1}

Liquid effluent discharges require the decision tree analysis that begins on page 1 of Figure 5-1.

\section{Is Effluent a Domestic Wastewater?}

As defined in WAC 173-216-030(4), domestic wastewaters are water carrying human wastes, including kitchen, bath, and laundry wastes from residences, buildings, industrial establishments or other places, together with such ground water infiltration or surface waters as may be present. Examples of these wastewaters at the Hanford Site include sanitary wastewaters from bathrooms, showers, and kitchen areas discharged to the sanitary sewer system. The 100-N, 300 and 400 Area sanitary sewage systems are identified in Table 4 of the Consent Order and are subject to permitting milestones provided therein. Sanitary wastewaters in the 1100 Area discharge to the City of Richland sewer system. The remaining sanitary wastewaters are discharged to septic tanks on the Hanford Site.

Is discharge from a septic tank with subsurface sewage treatment and disposal and an ultimate design capacity less than or equal to 14,500 gallons per day?

If the septic system meets this criteria, then per WAC. 173-216-050(f), the systems are governed by WAC 246-172 (recodified from VAC 248-96), which is administered by the Washington State Department of Social and Health Services. 


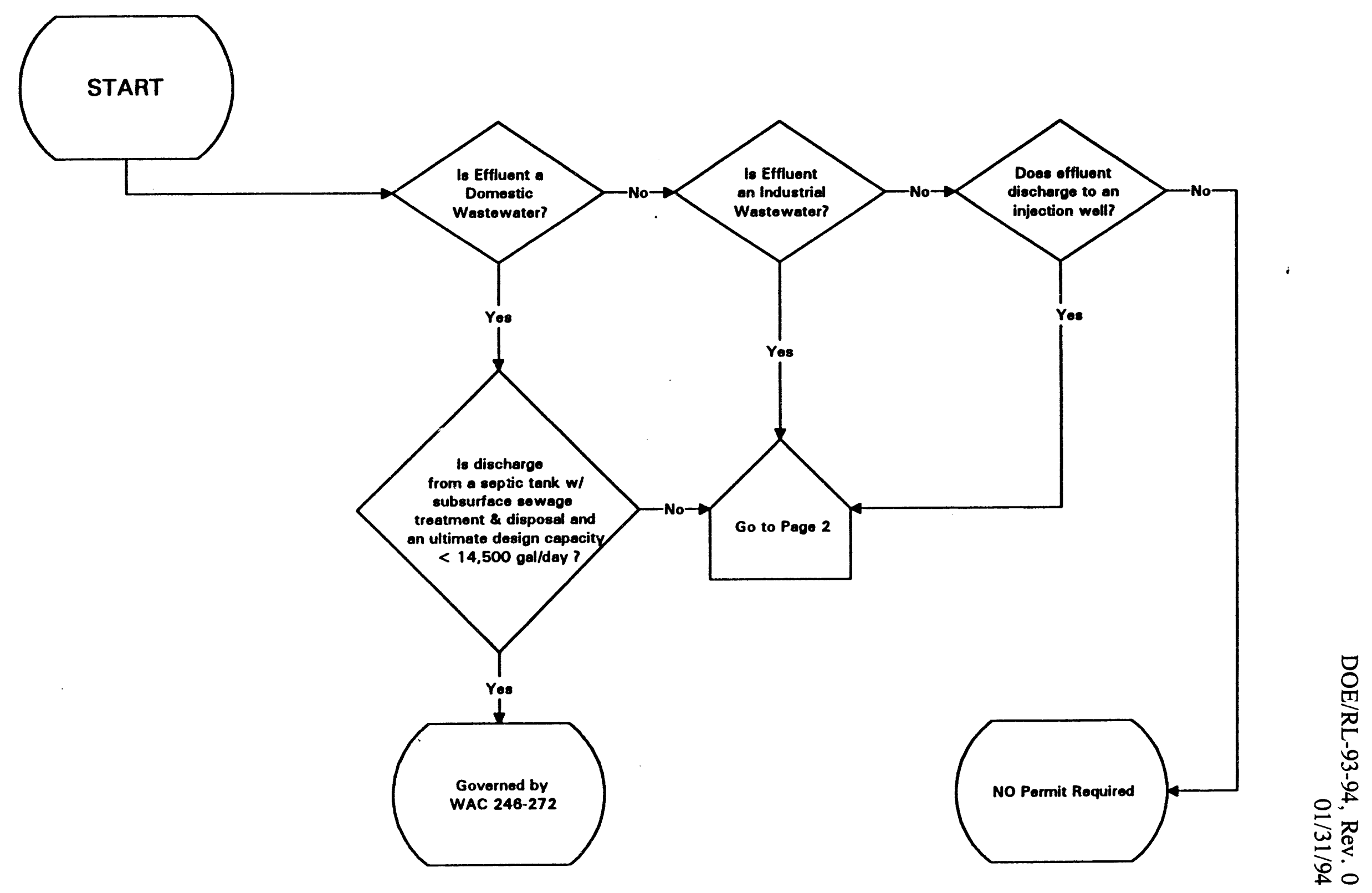

Figure 5-1. Plan for Disposition of Miscellaneous Streams Discharging to Land (1 of 3) 


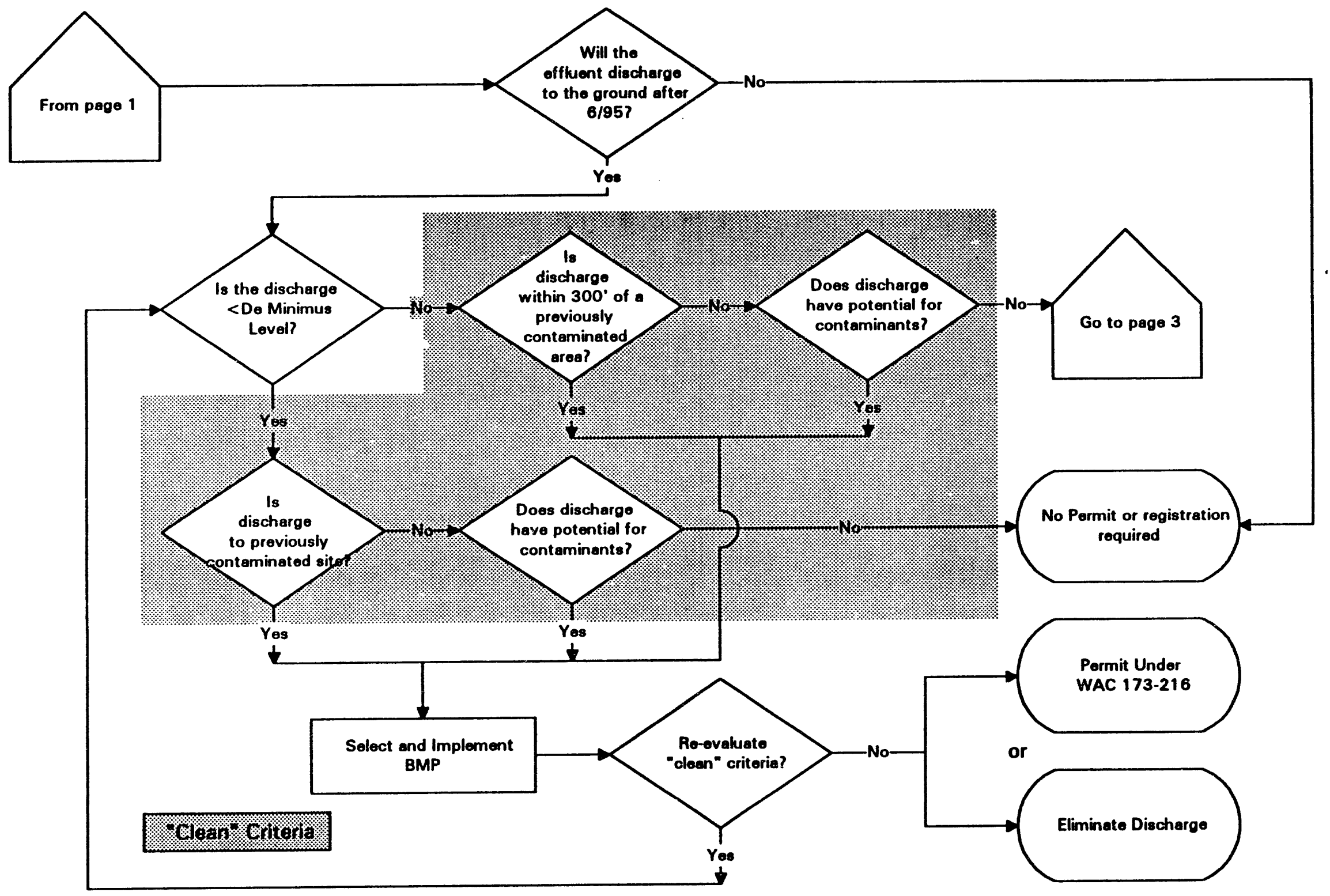

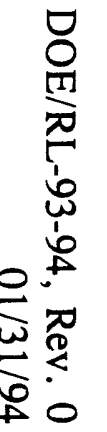

Figure 5-1. Plan for Disposition of Miscellaneous Streams Discharging to Land (2 of 3) 


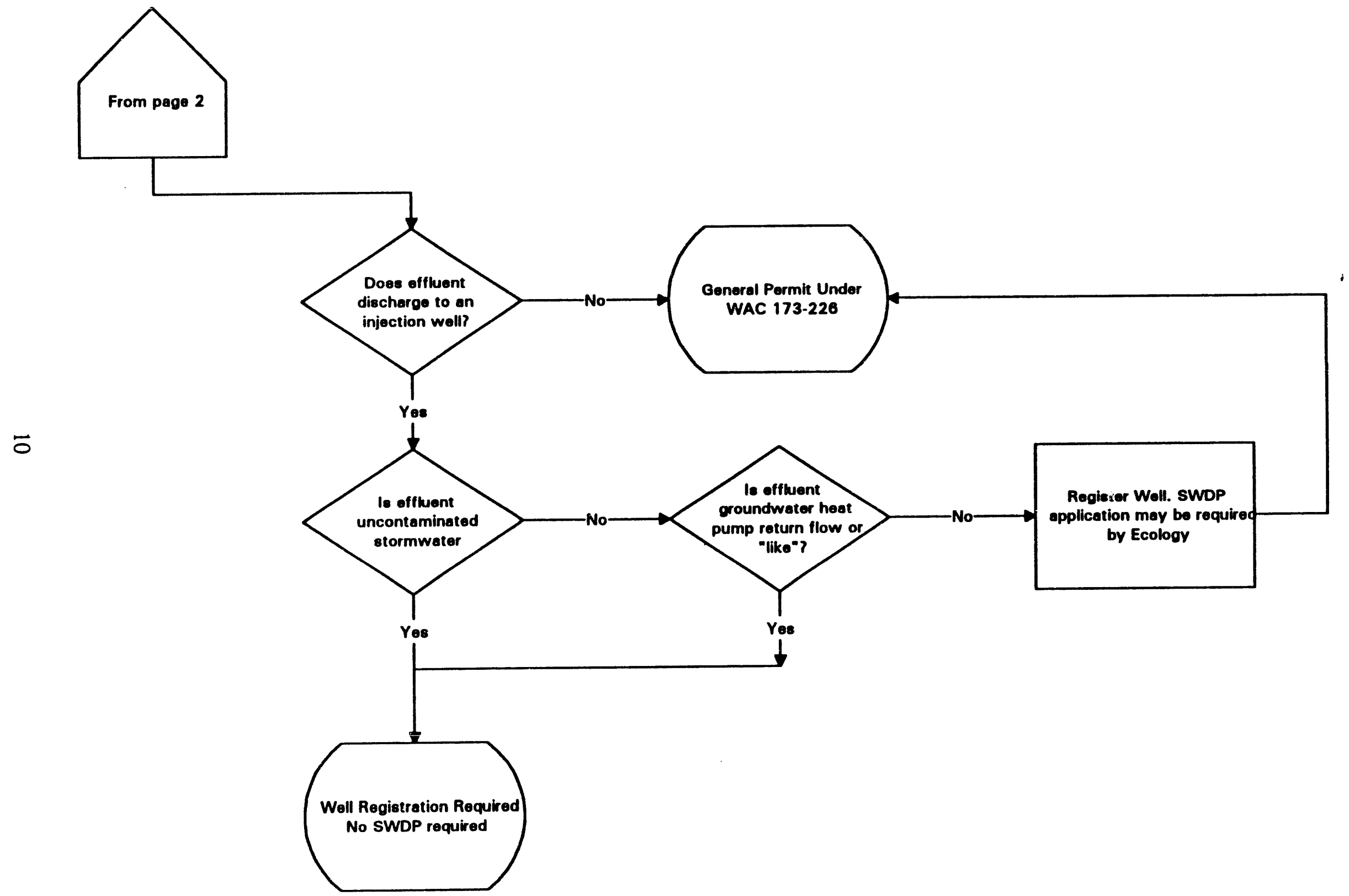

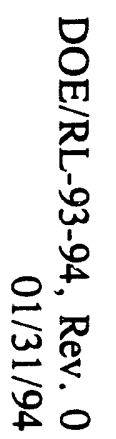

Figure 5-1. Plan for Disposition of Miscellaneous Streams Discharging to Land (3 of 3) 


\section{Is the Effluent an Industrial Wastewater?}

Industrial wastewaters are defined WAC 173-216-030(7) as water or liquid carried waste from industrial or commercial processes, as distinct from domestic wastewater, resulting from any process or activity of industry, manufacture, trade or business, from the development of any natural resource, or from animal operations such as feed lots, poultry houses, or dairies. The term includes contaminated stormwater and leachate from solid waste facilities.

\section{Does effluent discharge to an injection well?}

As defined in WAC 173-218-030 $(11,18)$, an injection well is a bored, drilled, or driven shaft or dug hole whose depth is greater than the largest surface dimension, that is used for the subsurface emplacement of fluids.

If the liquid effluent is determined not to be a domestic wastewater or an industrial wastewater and is not discharged to an injection well, the regulations in WAC 173-216, 173218, or 173-226 are not considered applicable to these types of wastes, and, therefore, a State Waste Discharge Permit would not be required. Examples of wastes not subject to these regulations are irrigation water used for aesthetics and water discharged during fire sprinkler tests.

\subsection{CLARIFICATION AND JUSTIFICATION - FIGURE 5-1, PAGE 2}

Liquid effluent discharges directed to page 2 of Figure 5-1 in the decision tree analysis require the following analysis to ascertain proper disposition:

Is the liquid effluent discharge rate less than 10 gallons per minute or the total discharge volume less than 14.500 gallons per day?

The purpose of this determination is to apply a de minimus level for discharge rates (in the cast of continuous discharge) or total discharge volume (in the case of batch discharge). The de minimus level of 10 gallons per minute and 14,500 gallons per day is proposed. The level is based on criteria set in WAC 173-216-050(f) that domestic wastewater from a septic system discharging less than or equal to 14,500 gallons per day (approximately 10 gallons per minute) to the soil is not subject to the state waste discharge permitting requirements. The assumption for this criterion is that Ecology considers discharges less than 14,500 gallons per day as having no significant potential to adversely affect the ground water. The de minimus level is one of a series of criteria presented in the decision tree analysis to determine necessary actions for acceptable management of the Miscellaneous Streams. It is recognized that because of the strict nature of the language contained in WAC 173-216, this de minimus level may be too high and another level may be negotiated. However, if this happens, this does not effect the overall logic and implementability of this Plan and Schedule. 
A State Waste Discharge Permit or well registration per WAC 173-218 (if applicable) is not required if a Miscellaneous Stream has a discharge rate less than the de minimus level and meets the "clean" criteria as presented in Figure 5-1. The Miscellaneous Stream is not considered a "clean" wastewater, if any of the following questions are answered with a "yes":

1. Is the discharge within a surface contaminated area? Provided the discharge rate is less than the de minimus level, the subsequent criterion to be considered is the potential for effecting migration of existing contaminants present in the soil of the discharge site to the ground water. For discharges less than the de minimus level, the concern is with Miscellaneous Streams discharging directly to a surface contaminated area. Surface-contaminated areas are defined as those soils contaminated with dangerous and/or radioactive wastes.

2. Is the discharge within a 300 -foot horizontal radius of an active or inactive contaminated crib, ditch, trench? For liquid effluent discharges exceeding the de minimus level, the potential for migration of existing contaminants present in the soil within a 300 -foot radius of the discharge point is considered. The 300 feetcriterion is a recommended minimum separation distance for siting new cribs at the Hanford Site. It is considered a conservative distance based on collective experience at the Hanford Site from borehole drilling in the vicinity of liquid effluent disposal sites. Lateral spreading from adjacent liquid disposal sites greater than 300 feet apart has not been observed to impact either disposal stream. This will include streams discharging directly to a surface contaminated area.

3. Does the discharge have potential for contaminants? The acceptable effluent quality is based on evaluating the potential for constituents listed in the Ground Water Quality Standards (Table 1 of WAC 173-200) to enter the source water and cause the criteria to be exceeded. Miscellaneous Streams originating from sources with physical and/or administrative barriers to prevent contaminants from entering the stream are not considered to have a potential for contaminants. Raw or sanitary wastewater unaltered except for temperature, which consists of a large portion of the inventory (i.e., steam condensate, uncontaminated stormwater, noncontact cooling water) is not considered to have the potential for contaminants.

\section{No permit or registration required}

The Miscellaneous Stream is not required to be permitted under the State Waste Discharge Program (WAC 173-216) provided that the Miscellaneous Stream meets the de minimus criteria, does not discharge to a contaminated area and does not have the potential for contaminants to enter the stream. If the discharge is to an injection well, the registration of that well under WAC 173-218 is also not required. This determination is based on promulgating the exclusion of liquid effluents meeting a de minimus discharge rate and the "clean criteria" presented in Figure 5-1, from the requirements for the submittal of State Waste Discharge Permit applications or other compliance documentation under WAC 173- 
216, 173-218 and/or 173-226. This determination is consistent with the intent of the Tri-Party Agreement that only "those waste water streams currently discharged to the soil column or any future waste water streams (excluding discharges that are exempt from permitting under Section 121 of CERCLA) discharged to the soil column, which affect ground water or have the potential to affect ground water, . . . be subject to the provisions of the State Waste Discharge Permit Program.

\section{Evaluate and Implement Best Management Practices (BMP)}

Miscellaneous Streams with the potential to affect ground water, (e.g., those discharges identified through the decision tree analysis in Figure 5-1 to have the potential to effect migration of contaminants from surface-contaminated areas, cribs, ditches, and trenches to the ground water, or have the potential for contaminants to enter the stream) require the selection and implementation of best management practices (BMP). Selection of the proper BMPs will address and identify contaminant sources and identify practices and procedures that will satisfy the "clean" criteria of the decision tree analysis in Figure 5-1. BMPs as defined in WAC 173-200 are schedules of activities, prohibition of practices, maintenance of procedures, and other management practices, to prevent or reduce the pollution of ground waters of the state. BMPs also include treatment requirements, operating procedures and practices to control plant site runoff, spillage or leaks, sludge or water disposal, or drainage from raw material storage. Baseline BMPs that should at minimum be implemented for these streams include good housekeeping, preventative maintenance, visual inspections, employee training, and recordkeeping and reporting.

For those Miscellaneous Streams that cannot satisfy the "clean" criteria of the decision tree analysis, even after implementation of BMPs, a decision is required to either eliminate the discharge or pursue a State Waste Discharge Permit for the individual Miscellaneous Stream under WAC 173-216.

\subsection{CLARIFICATION AND JUSTIFICATION - FIGURE 5-1, PAGE 3}

Miscellaneous Streams exceeding the de minimus discharge rate or volume, but satisfying the "clean" criteria, are subject to resolution of the questions in the decision tree (page three of Figure 5-1) to determine the necessary actions for regulatory compliance.

\section{Does effluent discharge to an injection well?}

As defined in WAC 173-218-030 $(11,18)$, an injection well is a bored, drilled, or driven shaft or dug hole whose depth is greater than the largest surface dimension, used for the subsurface emplacement of fluids.

The injection wells receiving Miscellaneous Streams at the Hanford Site are Class V injection wells. Per WAC 173-218-090, all persons operating an existing Class V injection well that inject industrial, commercial, or municipal waste fluids into or above an Underground Source of Drinking Water (USDW), must apply to Ecology for approval to operate within one year of the effective date of the regulation (WAC 173-218). RL and 
Ecology agreed through the Tri-Party Agreement negotiations and the subsequent Consent Order that the liquid effluents discharged to soil at Hanford would be best addressed through WAC 173-216/218 (where applicable). The Hanford Site is required to meet the schedules for compliance with the applicabie regulations set forth in the Consent Order. The schedules are considered to supersede the applicable dates promulgated within the regulations. Therefore, the effective date for the Hanford Site to submit applications for operating existing Class V injection wells (receiving Miscellaneous Streams) is considered to be the schedule defined within this document.

In WAC 173-218-030, "waste fluids" are defined as discarded, abandoned, unwanted, or unrecovered material or substance that flows or moves whether in a semisolid, liquid, sludge, gas, or any other form or state except discharges into the ground or ground water of groundwater heat pump return flow (unaltered except for temperature), and discharges of storm water not contaminated or potentially contaminated by industrial or commercial sources.

Is the effluent uncontaminated stornwater, or is the effluent ground water heat pump return flow (unaltered except for temperature) or "like"?

Uncontaminated stormwater and ground water heat pump return flow are not considered "waste fluids" and therefore, Class V injection wells receiving these waste types are only required to register the well on a form prescribed by Ecology. Steam condensate from traps along a steam line is considered to be "like" groundwater heat pump return flow (unaltered except for temperature).

As stated in WAC 173-218-090(2), Class V injection wells receiving industrial, commercial or municipal "waste fluids" must apply to Ecology for operation of these wells. Ecology will accep:, process, and act upon the application in accordance with the procedures and practices of the State Waste Discharge Permit Program under WAC 173-216.

\section{Permit liquid effluents under a general state waste discharge permit}

Ecology will be requested to develop a general permit under the State Waste General Discharge Permit Program (WAC 173-226), for all Miscellaneous Streams satisfying the criteria of the decision tree analysis. These include:

- Liquid effluent discharge rates or total volumes exceeding 10 gallons per minute or 14,500 gallons per day, respectively.

- Liquid effluents discharging to sites outside of a 300 -foot radius from a surface contaminated area, trench, ditch or crib.

- Liquid effluent discharges that do not have the potential for contaminants to enter the stream. 
In addition, Ecology would be petitioned to include in the general permit those Miscellaneous Streams determined to be waste fluids discharging to an injection well, if Ecology deemed a State Waste Discharge Permit necessary.

\subsection{SCHEDULE FOR DISPOSITION AND REGULATORY COMPLIANCE OF MISCELLANEOUS STREAMS}

Table 6-1 identifies specific milestones that have been established for activities associated with the planned disposition of the Miscellaneous Streams. These activities correspond to actions identified as a result of performing the decision tree analysis presented in Figure 5-1. The applicability column of Table 6-1 provides reference to the category of liquid effluents requiring the specified action. 


\section{Table 6-1. Schedule for Disposition and Regulatory Compliance of the Miscellaneous Streams}

\begin{tabular}{|c|c|c|}
\hline Activity & Applicability & Schedule for Submittal \\
\hline $\begin{array}{l}\text { Evaluate inventory to de } \\
\text { minimus criteria }\end{array}$ & $\begin{array}{l}\text { All streams identified in quantitative and } \\
\text { qualitative inventory except, streams to be } \\
\text { eliminated by } 6 / 95 \text { or rerouted to permitted } \\
\text { treatment facility or stream, and purge } \\
\text { water from wells. }\end{array}$ & $\begin{array}{l}1 \text { month following } \\
\text { establishment of Ecology } \\
\text { approved de minimus criteria }\end{array}$ \\
\hline $\begin{array}{l}\text { Evaluate inventory to criteria } \\
\text { established in Figure } 5-1\end{array}$ & $\begin{array}{l}\text { All streams identified in quantitative and } \\
\text { qualitative inventory except, streams to be } \\
\text { eliminated by } 6 / 95 \text { or rerouted to permitted } \\
\text { treatment facility or stream, and purge } \\
\text { water from wells. }\end{array}$ & $\begin{array}{l}3 \text { months following } \\
\text { establishment of Ecology } \\
\text { approved de minimus criteria. }\end{array}$ \\
\hline $\begin{array}{l}\text { Petition Ecology to develop } \\
\text { general permit under WAC } \\
173-226\end{array}$ & $\begin{array}{l}\text { Liquid effluent discharges requiring a } \\
\text { SWDP based on satisfying criteria from } \\
\text { decision tree analysis, as presented in } \\
\text { Figure } 5-1 \text {. }\end{array}$ & $\begin{array}{l}3 \text { months following } \\
\text { establishment of Ecology } \\
\text { approved de minimus criteria. }\end{array}$ \\
\hline $\begin{array}{l}\text { Register Class V injection } \\
\text { wells with Ecology }\end{array}$ & $\begin{array}{l}\text { Liquid effluent discharges requiring well } \\
\text { registration based on criteria presented in } \\
\text { Figure } 5-1 \text {. }\end{array}$ & $\begin{array}{l}3 \text { months following } \\
\text { establishment of Ecology } \\
\text { approved de minimus criteria. }\end{array}$ \\
\hline $\begin{array}{l}\text { Identify streams requiring } \\
\text { selection of BMP }\end{array}$ & $\begin{array}{l}\text { Liquid effluent discharges not meeting } \\
\text { "clean" criteria of the decision tree } \\
\text { analysis, as presented in Figure } 5-1 .\end{array}$ & $\begin{array}{l}3 \text { months following } \\
\text { establishment of Ecology } \\
\text { approved de minimus criteria. }\end{array}$ \\
\hline $\begin{array}{l}\text { Select and Initiate } \\
\text { Implementation of Best } \\
\text { Management Practices }\end{array}$ & $\begin{array}{l}\text { Liquid effluent discharges not meeting } \\
\text { "clean" criteria of the decision tree } \\
\text { analysis, as presented in Figure 5-1. }\end{array}$ & $\begin{array}{l}18 \text { months following } \\
\text { establishment of Ecology } \\
\text { approved de minimus criteria. }\end{array}$ \\
\hline $\begin{array}{l}\text { File necessary permit } \\
\text { applications under WAC 173- } \\
216 \text { for applicable streams }\end{array}$ & $\begin{array}{l}\text { Liquid effluent discharges not meeting } \\
\text { "clean" criteria of the decision tree } \\
\text { analysis, as presented in Figure } 5-1 \text { and } \\
\text { continuing to discharge after } 6 / 95 \text {. }\end{array}$ & $\begin{array}{l}18 \text { months following } \\
\text { establishment of Ecology } \\
\text { approved de minimus criteria. }\end{array}$ \\
\hline $\begin{array}{l}\text { Eliminate discharges not } \\
\text { satisfying "clean" criteria and } \\
\text { not applied for permit under } \\
\text { WAC 173-216 }\end{array}$ & $\begin{array}{l}\text { Liquid effluent discharges not meeting } \\
\text { "clean" criteria of the decision tree } \\
\text { analysis, as presented in Figure 5-1 and not } \\
\text { being permitted under WAC } 173-216 \text {. }\end{array}$ & $\begin{array}{l}24 \text { months following } \\
\text { establishment of Ecology } \\
\text { approved de minimus criteria. }\end{array}$ \\
\hline
\end{tabular}




\subsection{REFERENCES}

\subsection{DOCUMENTS AND LETTERS}

DOE-RL, 1987, Plan and Schedule to Discontinue Disposal of Contaminated Liquids into the Soil Column at the Hanford Site, DOE-065, Response to Congressional Request, U.S. Department of Energy, Richland Operations Office, Richland, Washington.

DOE-RL, 1990, Letter from R.D. Izatt to President, Hanford Environmental Health Foundation; General Manager, Kaiser Engineers Hanford Company; Director, Pacific Northwest Laboratory; President, Westinghouse Hanford Company, Strategy for Handling and Disposing of Purgewater at the Hanford Site, Washington, 90-ERB-076, August 9, 1990.

Ecology, EPA, and DOE, 1992, Hanford Federal Facility Agreement and Consent Order, 89-10 Rev. 2, Washington Department of Ecology, U.S. Environmental Protection Agency, an U.S. Department of Energy, Olympia Washington.

Ecology and USDOE, 1991, Consent Order No. DE 91NM-177, Washington Department of Ecology, U.S. Department of Energy, Olympia Washington.

Stordeur, R.T. and D.L. Flyckt, 1988, Annual Status Report of the Plan and Schedule to Discontinue Disposal of Contaminated Liquids into the Soil Column at the Hanford Site, WHC-EP-0196-1, Westinghouse Hanford Company, Richland, Washington.

WHC, 1992, Plan and Schedule for Identification and Evaluation of All Miscellaneous Streams (September 1992), WHC-SD-EN-EV-017, Rev. 0, Westinghouse Hanford Company, Richland, Washington.

\subsection{CODE OF FEDERAL REGULATIONS AND FEDERAL REGISTER}

Comprehensive Environmental Response, Compensation, and Liability Act of 1980, 42 USC 9601 et seq.

\subsection{FEDERAL AND STATE ACTS}

Water Pollution Control, Revised Code of Washington, Chapter 90.48 et seq., Olympia, Washington.

\subsection{WASHINGTON ADMINISTRATIVE CODE}

WAC 173-216, State Waste Discharge Program, Washington State Department of Ecology, Olympia, Washington.

WAC 173-218, State Undergrouna Injection Control Regulations, Washington State Department of Ecology, Olympia, Washington. 
WAC 173-220, National Pollutant Discharge Elimination Syster. (NPDES) Permit Program, Washington State Department of Ecology, Olympia, Washington.

WAC 173-226, State Waste Discharge General Permit Program, Washington State Department of Ecology, Olympia, Washington.

WAC 246-272, On-Site Sewage System, Washington State Department of Ecology, Olympia, Washington. 


\title{
DISTRIBUTION
}

\begin{abstract}
Number of Copies
\end{abstract}
ONSITE

10

U.S. Department of Energy-

Field Office, Richland

J. D. Berwick

R3-80

D. A. Brown

$\mathrm{K} 8-50$

D. C. Bryson (2)

J. M. Hennig

A5-21

J. E. Rasmussen

A5-21

J. E. Turnbaugh

A5- 15

W. A. White

Public Reading Room (2)

A5-15

A7-27

A1-65

3

Dacific Northwest Laboratory

Hanford Technical Library

$\mathrm{K} 1-11$

E. G. Damberg

P7 -70

F. E. Erickson

P7-79

12

Kaiser Engineers Hanford Company

J. L. Day

L6-76

J. M. Ekstrum

S2-32

R. L. Fritz

$\mathrm{S} 2-12$

A. Greenburg

S2-66

R. E. Hammond

L6-75

D. R. Herman

S2-12

C. W. Johnson, Jr.

S3-55

T. J. Lazarski

G7 -33

C. E. Marple

S2-34

A. D. Poor

L6-55

W. A. Retterer

S2-37

S. C. Sutton

S2-37

Westinghouse Hanford Company

D. J. Carrell

H6-22

A. J. Diliberto

R3-46

R. D. Gustavson

R1-51

D. L. Halgren

M. J. Ha11

H6-70

D. R. Hirze1

T6-07

G. S. Hunachek

T5-54

M. C. Hughes

$\times 0-41$

J. E. Lessor

G. J. Lebaron

$\times 5-55$

S6-70

J. Lohrasbi

S6-19

K. J. Lueck

S6-19

H6-28 


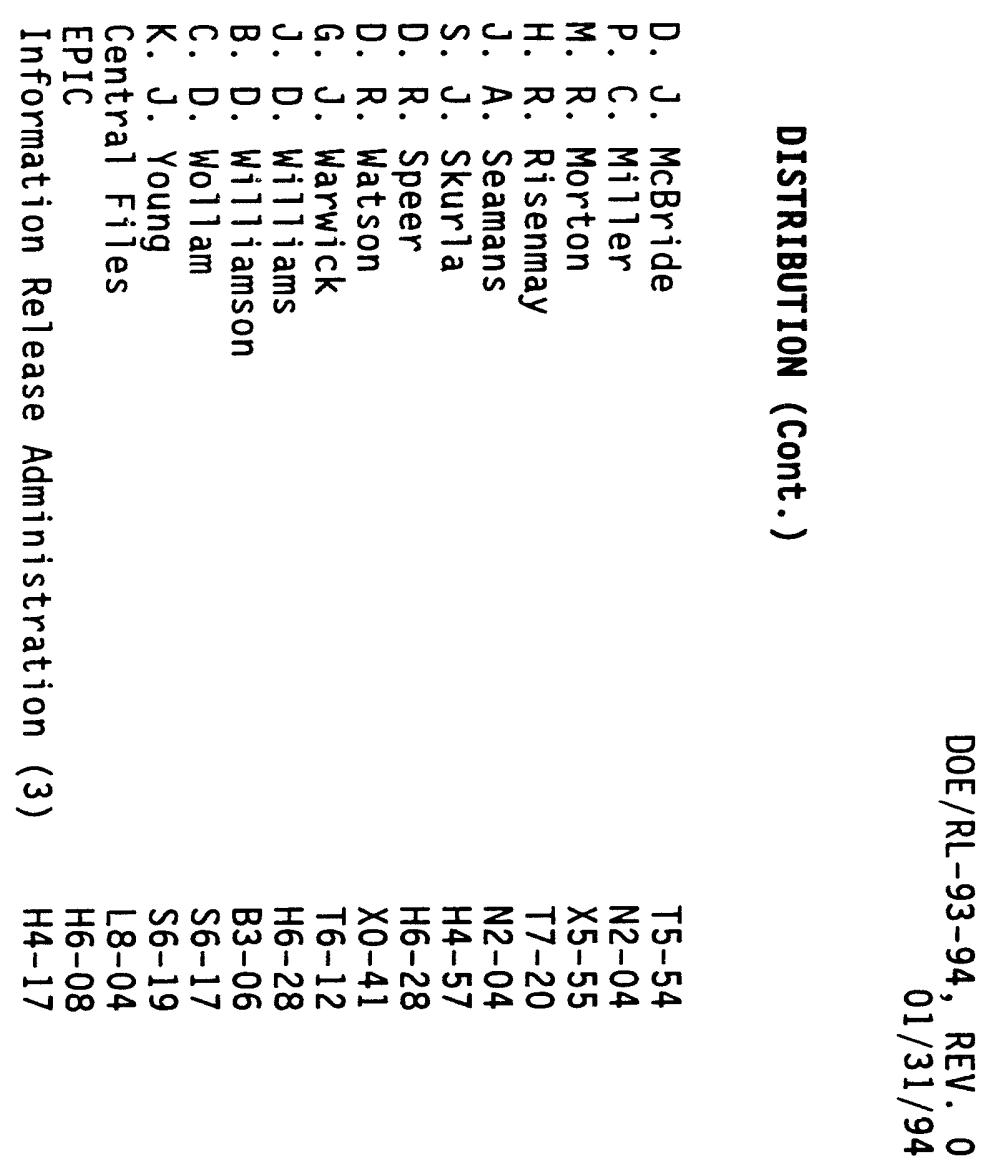




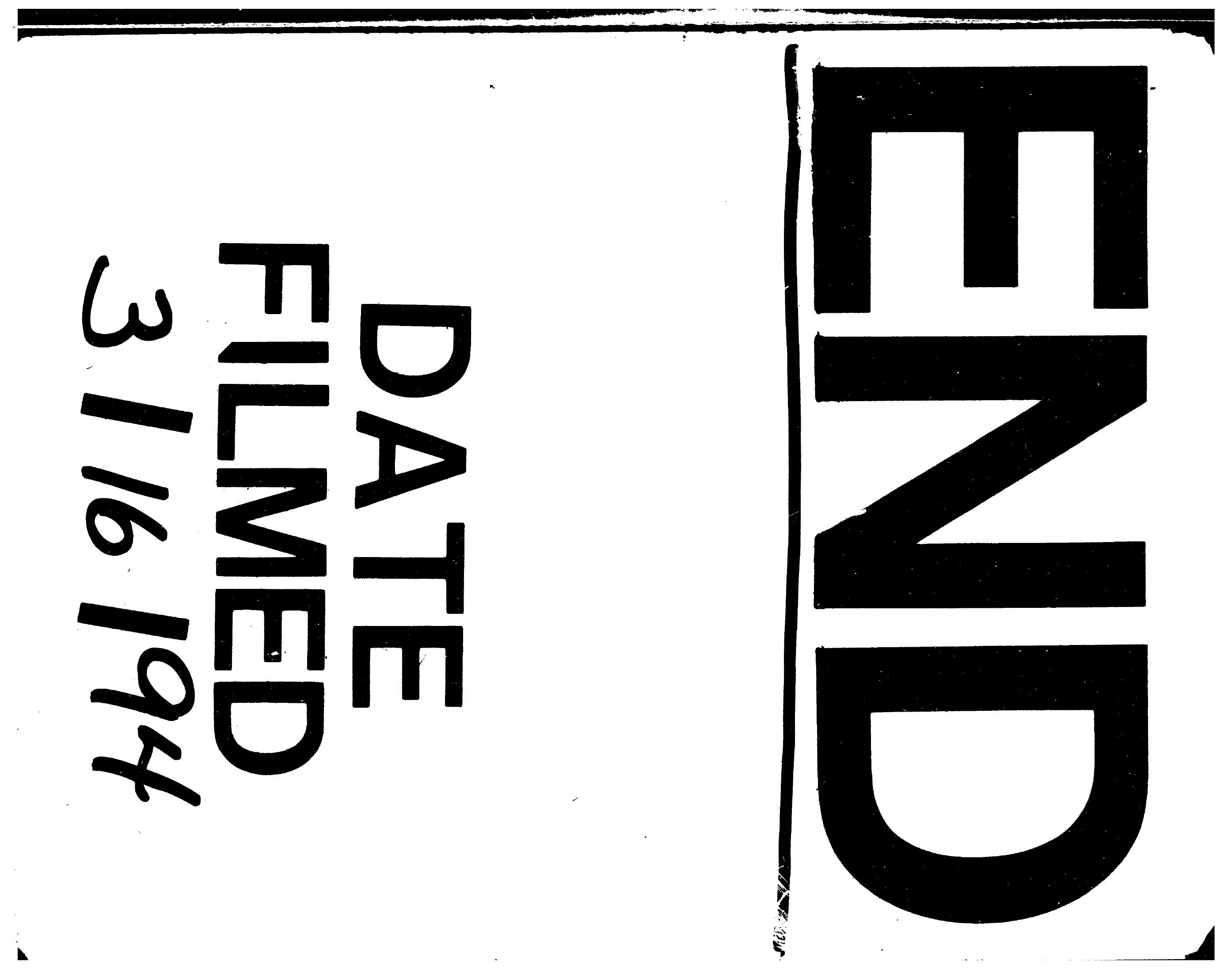




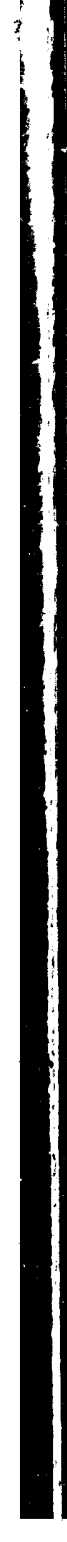

- 